Ida Poljanšek*, Primož Oven, Viljem Vek, Jan-Erik Raitanen, Jarl Hemming and Stefan Willför

\title{
Isolation of pure pinosylvins from industrial knotwood residue with non-chlorinated solvents
}

https://doi.org/10.1515/hf-2018-0152

Received July 4, 2018; accepted November 13, 2018; previously

published online December 22, 2018

\begin{abstract}
The aim of the study was to find appropriate non-chlorinated solvent systems for the extraction and separation of pure pinosylvin (PS) and pinosylvin monomethylether (PSMME) from Scots pine/Norway spruce wood residues. The extraction was performed in a pressurized solvent extractor and the purification and isolation of pure substances was done by flash chromatography. More precisely, pure PS was isolated via sequential flash chromatography in two repetitions in the gradient mode of the mobile phase, with cylcohexane (CX) and ethylacetate (EtOAc), beginning with 100\% CX and ending up with 100\% EtOAc. The extractives were qualitatively and quantitatively analyzed in terms of PS and PSMME contents by gas chromatographyflame ionization detector (GC-FID), gas chromatographymass spectrometry (GC-MS), high-performance liquid chromatography (HPLC) and proton nuclear magnetic resonance ( $\left.{ }^{1} \mathrm{H}-\mathrm{NMR}\right)$ spectroscopy.
\end{abstract}

Keywords: extractives, isolation, knots, non-chlorinated solvents, pinosylvin, wood residue

\section{Introduction}

In recent years, much attention has been paid to plant polyphenols, which are considered to be health-promoting compounds. Stilbenes are one of the important polyphenol groups, of which resveratrol is the most investigated compound (Figure 1). Resveratrol is relevant because of its antimicrobial effect against various

\footnotetext{
*Corresponding author: Ida Poljanšek, Department of Wood Science and Technology, Biotechnical Faculty, University of Ljubljana, Jamnikarjeva 101, Ljubljana SI-1000, Slovenia,

e-mail: ida.poljansek@bf.uni-lj.si

Primož Oven and Viljem Vek: Department of Wood Science and Technology, Biotechnical Faculty, University of Ljubljana, Jamnikarjeva 101, Ljubljana SI-1000, Slovenia Jan-Erik Raitanen, Jarl Hemming and Stefan Willför: Johan Gadolin Process Chemistry Centre, Åbo Akademi University (AAU), Turku/Åbo, Finland
}

bacteria and dermatophytic fungi (Chan 2002; Lindberg et al. 2004; Välimaa et al. 2007). Another interesting compound from this group is pinosylvin (PS) (Figure 1), which also showed antimicrobial activity and cytotoxicity against a murine hepatic carcinoma cell line (Välimaa et al. 2007).

Woody biomass including conifers and broadleaved species contain large amounts of extractable phenolic compounds in their heartwood and especially in the knots (Willför et al. 2003a,b,c; Pietarinen et al.2006; Willför et al. 2007; Conde et al. 2014). Knots of softwood mainly contain lignans, oligolignans and stilbenes, whereas the characteristic compounds of wood from the genus Pinus are the stilbenes, PS and pinosylvin monomethyl ether (PSMME) (Figure 1) (Willför et al. 2003a; Willför et al. 2007). Knots are waste material in paper mills and must be eliminated from pulp due to their high content of extractives, which cause pitch deposition on paper (Allen 1980; Farrell et al. 1993; Gutierrez et al. 2001). Eckerman and Holmbom (2001) developed a convenient process for the separation of knots from oversized wood chips before pulping.

The extraction parameters for the isolation of specific polyphenols from Scots pine (Pinus sylvestris), such as stilbenes and lignans, were investigated by Fang et al. (2013). The polyphenol yields depend on the solvent polarity, extraction temperature and extraction time. Sequential extractions of pine knots with cylcohexane (CX) and EtOH/ water mixture $(95 / 5, \mathrm{v} / \mathrm{v})$ was suggested for the production of PSs and nortrachelogenin (NTG) with high yields and high purity. Fang et al. (2013) proposed hot-water extraction for the recovery of NTG from the knots of Scots pine. In the present study, it was decided to use $\mathrm{CX}$ and EtOH/ water $(95 / 5, v / v)$ for the sequential extractions and hot water for the non-sequential extraction for the recovery of extractives from an industrial sample.

The chemical structures of some important stilbenes and lignans are presented in Figure 1. For food applications, the isolated substances must be of high purity. To obtain pure PS from woody biomass, chlorinated solvents, e.g. dichloromethane, are frequently described in the literature (Välimaa et al. 2007; Plumed-Ferrer et al. 2013). Different time-consuming multistage extraction procedures are also known (Celimene et al. 1999; Nilsson et al. 2002; Simard et al. 2008). However, PS isolation from knotwood on an industrial scale has other requirements, 
<smiles>Oc1cc(O)cc(/C=C/c2cc(O)cc(/C=C/c3ccccc3)c2)c1</smiles><smiles>COc1cc(C[C@@H]2C(=O)OC[C@H]2[C@H](O)c2ccc(O)c(OC)c2)ccc1O</smiles><smiles>COc1cc(C[C@H]2COC(=O)[C@]2(O)Cc2ccc(O)c(OC)c2)ccc1O</smiles>

Figure 1: Structures of the stilbenes resveratrol, pinosylvin and pinosylvin monomethyl ether and two lignans, HMR and NTG.

e.g. the use of non-chlorinated solvents, which have not yet been investigated.

The aim of the present work was therefore to develop a procedure that can be applied in large-scale extraction, isolation and purification for the industrial production of PS and PSMME for food applications. The source of these substances are pulping residuals with around 60\% knotwood content from Norway spruce (Picea abies) and Scots pine, and the main challenge is an effective separation and isolation with non-chlorinated solvents. The chemical characterization of the hydrophilic extracts and pure isolated compounds belongs to the research objectives and was performed by gas chromatography-flame ionization detection (GC-FID), gas chromatography-mass spectrometry (GCMS), high-performance liquid chromatography (HPLC) and proton nuclear magnetic resonance ( $\left.{ }^{1} \mathrm{H}-\mathrm{NMR}\right)$ spectroscopy.

\section{Materials and methods}

Chemicals and reagents: All the solvents and reagents were of analytical grade. $\mathrm{CX}, \mathrm{MeOH}$, EtOH, ethyl acetate (EtOAc), acetone, petroleum ether (PET), dichloromethane $\left(\mathrm{CH}_{2} \mathrm{Cl}_{2}\right)$ and sulfuric acid, as well as the reference compounds for the chromatographic analysis were purchased from Sigma Aldrich (Steinheim, Germany). The references were PS (HPLC, $\geq 97 \%$ ), PSMME (HPLC, $\geq 97 \%$ ), pinostilbene hydrate (PiSb, HPLC, $\geq 95 \%$ ), pterostilbene (PtSb, HPLC, $\geq 97 \%$ ), pinobanksin (PB, HPLC, $\geq 95 \%$ ), NTG (HPLC, $\geq 95 \%$ ) and pinocembrin (PC, HPLC, $\geq 95 \%$ ).

Wood material: The industrial sample was taken from over-sized chips in a Finnish pulp mill. The sample contained a mixture of Norway spruce and Scots pine knots, with an approximate pine/ spruce ratio of $60 / 40$ with around $60 \%$ knot content. The chips for milling were dried at room temperature. Homogenization and milling of samples were carried out in a Retsch SM 2000 (Retsch GmbH, Haan, Germany) cutting mill, producing particles that passed through a 10 mesh $(1.85 \mathrm{~mm})$ screen. The wood meal sample was then transferred into plastic bags and stored in the dark at $8^{\circ} \mathrm{C}$ until further processing. The freeze-drying step after milling ensured almost complete removal of volatile compounds.

Extraction procedure: The samples were freeze-dried for $24 \mathrm{~h}$ in a Christ Alpha 1-4 LDplus lyophilisator (Christ, Osterode am Harz, Germany) and the extractions were performed in an accelerated solvent extraction (ASE) apparatus (Dionex Corp., Sunnyvale, CA, USA). The dried samples ( $30 \mathrm{~g}$ ) were transferred to a stainless-steel extraction cell, which was appropriately closed with filter paper, a metal frit and a plug screw. The extractor was first flushed ( $5 \mathrm{~min}$ ) with a suitable solvent to remove all the impurities and solvent leftovers from the system.

Lipophilic and hydrophilic compounds were subsequently extracted using $\mathrm{CX}$ as a non-polar solvent and an $\mathrm{EtOH} /$ water mixture $(95 / 5, v / v)$, which is best suited for the extraction of more polar extractives (Willför et al. 2003a,b). Subsequent extraction with CX and $\mathrm{EtOH} /$ water is a standard procedure for PS isolation in good yields (23.3-41.8 $\mathrm{mg} \mathrm{g}^{-1}$ ) (Fang et al. 2013). This was the first hydrophilic extract (ethanol extract). For comparison, a second hydrophilic extract was obtained by extraction with only water (water extract). Water is the most appropriate solvent because of its low toxicity. The extraction conditions (Table 1) were selected based on preliminary tests. The obtained extracts were collected and evaporated to dryness in a vacuum evaporator. The temperature of the water bath was kept at $40^{\circ} \mathrm{C}$. One flask each of CX, EtOH and water extracts were stored in labeled $250 \mathrm{ml}$ glass bottles and kept at $4^{\circ} \mathrm{C}$ in the dark until further analysis.

After ASE extraction, the water extract was liquid-liquid (L-L) extracted using EtOAc and the composition of the EtOAc phase was analyzed using GC (ASE+L-L extraction with EtOAc). A second L-L extraction of the water ASE extract was performed using EtOAc in the presence of $\mathrm{NaCl}$ for better ionic strength (ASE+L-L extraction with $\mathrm{EtOAc}+\mathrm{NaCl})$ and the composition of the EtOAc phase was analyzed using GC (Table 2). 
Table 1: Conditions for the first and second extraction.

\begin{tabular}{llll}
\hline & \multicolumn{2}{c}{ First extraction with $\mathbf{C X}$ and EtOH/ $\mathbf{H}_{2} \mathbf{O}$} & Second extraction with $\mathbf{H}_{2} \mathbf{O}$ \\
\cline { 2 - 4 } Parameter & Lipophilic extract & Hydrophilic extract & Hydrophilic extract \\
\hline Temp. & $90^{\circ} \mathrm{C}$ & $100^{\circ} \mathrm{C}$ & $140^{\circ} \mathrm{C}$ \\
Pressure & $13.4 \mathrm{Bar}$ & $13.4 \mathrm{Bar}$ & $13.4 \mathrm{Bar}$ \\
Solvent & $100 \% \mathrm{CX}$ & $95 \% \mathrm{EtOH}+5 \% \mathrm{H}_{2} \mathrm{O}$ & $100 \% \mathrm{H}_{2} \mathrm{O}$ \\
Cell & $100 \mathrm{ml}$ & $100 \mathrm{ml}$ & $100 \mathrm{ml}$ \\
Vial volume & $250 \mathrm{ml}$ & $250 \mathrm{ml}$ & $250 \mathrm{ml}$ \\
Cycles & $3 \times 5 \mathrm{~min}$ (static) & $3 \times 5 \mathrm{~min}$ (static) & $3 \times 5 \mathrm{~min}($ static) \\
\hline
\end{tabular}

CX, Cylcohexane.

Table 2: Content of phenolic compounds and wood resins of the industrial sample extracted with different solvents: PSMME, PS, NTG and HMR.

\begin{tabular}{|c|c|c|c|c|c|c|c|c|}
\hline \multirow[b]{2}{*}{$\begin{array}{l}\text { Extraction } \\
\text { method }\end{array}$} & \multicolumn{3}{|c|}{ Pinosylvins } & \multirow[b]{2}{*}{$\begin{array}{r}\Sigma \text { of other stilbenes } \\
\left(\mathrm{mg} \mathrm{g}^{-1}\right)\end{array}$} & \multirow[b]{2}{*}{$\begin{array}{r}\mathrm{FA}+\mathrm{RA} \\
\left(\mathrm{mg} \mathrm{g}^{-1}\right)\end{array}$} & \multirow[b]{2}{*}{$\begin{array}{r}\text { HMR } \\
\left(\mathrm{mg} \mathrm{g}^{-1}\right)\end{array}$} & \multirow[b]{2}{*}{$\begin{array}{r}\text { NTG } \\
\left(\mathrm{mg} \mathrm{g}^{-1}\right)\end{array}$} & \multirow[b]{2}{*}{$\begin{array}{r}\boldsymbol{\Sigma} \text { of other lignan } \\
\left(\mathrm{mg} \mathrm{g}^{-1}\right.\end{array}$} \\
\hline & $\begin{array}{r}\text { PSMME } \\
\left(\mathrm{mg} \mathrm{g}^{-1}\right)\end{array}$ & $\begin{array}{r}\text { PS } \\
\left(\mathrm{mg} \mathrm{g}^{-1}\right) \\
\end{array}$ & $\begin{array}{r}\text { Total }^{\mathrm{a}} \\
\left(\mathrm{mg} \mathrm{g}^{-1}\right)\end{array}$ & & & & & \\
\hline \multicolumn{9}{|c|}{ Sequential extraction } \\
\hline Cyclohexane & 8.4 & 0.0 & 8.4 & 0.34 & 65.9 & 0.53 & 0.14 & 0.01 \\
\hline $\mathrm{EtOH} / \mathrm{W}(95 / 5)$ & 7.9 & 4.1 & 12.0 & 1,5 & 7.1 & 12.6 & 3.1 & 5.9 \\
\hline \multicolumn{9}{|c|}{ Non-sequential extraction } \\
\hline Water $140^{\circ} \mathrm{C}$ & 3.3 & 2.6 & 5.9 & 0.4 & 0.7 & 21.4 & 10.4 & 14.2 \\
\hline \multicolumn{9}{|c|}{ ASE+L-L extraction with EtOAc } \\
\hline Water $140^{\circ} \mathrm{C}$ & 3.1 & 2.6 & 5.7 & 0.36 & 0.7 & 20.3 & 9.8 & 13.7 \\
\hline \multicolumn{9}{|c|}{$\mathrm{ASE}+\mathrm{L}-\mathrm{L}$ extraction with EtOAc+NaCl} \\
\hline Water $140^{\circ} \mathrm{C}$ & 3.2 & 2.6 & 5.8 & 0.36 & 0.7 & 20.8 & 10.1 & 14.1 \\
\hline
\end{tabular}

$A S E+L-L$ extraction with EtOAc, EtOAc phase analyzed by GC. ASE+L-L extraction with EtOAc+NaCl (see text), EtOAc phase analyzed by GC. ${ }^{\mathrm{a}} \mathrm{mg} \mathrm{g}^{-1}$ based on freeze-dried wood.

FA, Fatty acids; RA, resin acids; ASE, accelerated solvent extraction; L-L, liquid-liquid; GC, gas chromatography.

Thin layer chromatography (TLC): TLC Silica gel 60 F254 aluminium sheets $\left(20 \times 20 \mathrm{~cm}^{2}\right)$ with a $20 \times 2.5 \mathrm{~cm}^{2}$ concentration zone (Merck KGaA, Darmstadt, Germany) were applied. A mixture of CX and ethyl acetate $(60 / 40, v / v)$ served as the developing solvent system. The analysis was performed in a saturated chromatographic chamber. For the visualization of the separated spots, spraying with $\mathrm{H}_{2} \mathrm{SO}_{4} /$ $\mathrm{EtOH} /$ water (25/50/25 by vol.) was done. The migration distance was $8 \mathrm{~cm}$. For separation, various solvent systems in different ratios (v/v) were tested, such as $\mathrm{CX} / \mathrm{EtOAc}$; $\mathrm{CX} /$ acetone; $\mathrm{CH}_{2} \mathrm{Cl}_{2} / \mathrm{EtOH}$ and EtOAc/ PET (Table 3). The $\mathrm{CH}_{2} \mathrm{Cl}_{2} / \mathrm{EtOH}(95 / 5 ; \mathrm{v} / \mathrm{v}$ ) solvent system was the reference mobile phase.

Flash chromatography: The hydrophilic extract was fractionated into pure compounds of PS, PSMME and lignans by flash column chromatography on normal-phase silica gel columns. The evaporated hydrophilic extract dissolved in a small volume of EtOH was applied on a flash cartridge (Biotage Si 40M, Biotage/Dyax; Flash chromatography 1L, Uppsala, Sweden). The velocity of the mobile phase was $5.08 \mathrm{~cm} \mathrm{~min}^{-1}\left(2 \mathrm{in} \mathrm{min}^{-1}\right)$. The hydrophilic extract was separated using a stepwise gradient of CX/EtOAc from 100:0 to 0:100 (v/v) [500 ml of 100\% CX, $1500 \mathrm{ml}$ of CX/EtOAc (80/20; v/v), $1000 \mathrm{ml}$ of CX/EtOAc (60/40; v/v), $500 \mathrm{ml}$ of $100 \%$ of EtOAc] and finally the column was washed with acetone until no spots could be observed on a TLC plate after separation. Each flash fraction (50 ml) was then analyzed using TLC, as described earlier, and the fractions containing pure PS and PSMME according to TLC (showing spots with similar retention factors) were combined and the solvent was evaporated to dryness in a vacuum evaporator. The purities of the isolated compounds were $>96 \%$ according to HPLC analysis.

Silylation of the extracts: Before the GC analysis, the hydrophilic extracts were derivatized according to Willför et al. (2003a,b,c). Four milliliters of hydrophilic extracts were transferred to $10 \mathrm{ml}$ vials and equipped with plastic screw caps. Betulinol $\left(0.02 \mathrm{mg} \mathrm{ml}^{-1}\right)$ and heneicosanoic acid (C21:0, $\left.0.02 \mathrm{mg} \mathrm{ml}^{-1}\right)$ served as the internal standards. Silylation agents were as follows: $80 \mu \mathrm{l}$ of $\mathrm{N}, \mathrm{O}$-bis(trimethylsilyl) trifluoroacetamide (BSTFA, Supelco Analytical, Bellefonte, PA, USA), $20 \mu \mathrm{l}$ of trimethylchlorosilane (TMCS, Merck KGaA, Darmstadt, Germany) and $20 \mu \mathrm{l}$ of pyridine $\left(70^{\circ} \mathrm{C}\right.$ for $\left.45 \mathrm{~min}\right)$. After cooling, the samples were transferred to $1.5 \mathrm{ml}$ vials with glass micro-inserts and analyzed by GC-FID.

Chromatographic analysis: GC-FID analyses were performed on a Perkin Elmer GC, AutoSystem XL system (Perkin Elmer Inc., Waltham, MA, USA) equipped with an HP-1 column (Agilent Technologies, Inc., Santa Clara, CA, USA; $25 \mathrm{~m} \times 0.20 \mathrm{~mm}$ i.d., film thickness $0.11 \mu \mathrm{m}) . \mathrm{H}_{2}$ was the carrier gas at a flow rate of $0.8 \mathrm{ml} \mathrm{min}^{-1}$. Details: split mode injection (ratio 1:24); temperature program: $120^{\circ} \mathrm{C}(1 \mathrm{~min}$ 
Table 3: Separation of sample extract and $R_{F}$ values for PSMME, PS, NTG and HMR with a series of solvent systems.

\begin{tabular}{|c|c|c|c|c|}
\hline Solvent system (v/v) & $R_{\mathrm{F}}$ PSMME & PS & NTG & HMR \\
\hline \multicolumn{5}{|l|}{$\mathrm{CX} / \mathrm{EtOAc}$} \\
\hline $30 / 70$ & 0.83 & 0.73 & 0.58 & 0.40 \\
\hline $50 / 50$ & 0.75 & 0.57 & 0.34 & 0.19 \\
\hline $60 / 40$ & 0.63 & 0.35 & 0.19 & 0.04 \\
\hline $70 / 30$ & 0.47 & 0.24 & 0.09 & 0.02 \\
\hline \multicolumn{5}{|l|}{$\mathrm{CX} /$ acetone } \\
\hline $50 / 50$ & 0.67 & 0.57 & 0.54 & 0.45 \\
\hline $60 / 40$ & 0.50 & 0.38 & 0.22 & 0.16 \\
\hline $70 / 30$ & 0.31 & 0.16 & 0.11 & 0.06 \\
\hline $80 / 20$ & 0.19 & 0.06 & $\mathrm{nd}^{\mathrm{a}}$ & $\mathrm{nd}^{\mathrm{a}}$ \\
\hline \multicolumn{5}{|l|}{$\mathrm{CCl}_{2} \mathrm{H}_{2} / \mathrm{EtOH}$} \\
\hline $96 / 4$ & 0.63 & 0.28 & nd & 0.25 \\
\hline \multicolumn{5}{|l|}{ EtOAc/PTE } \\
\hline $40 / 60$ & 0.71 & 0.33 & 0.13 & 0.04 \\
\hline $60 / 40$ & 0.88 & 0.83 & 0.60 & 0.47 \\
\hline \multicolumn{5}{|l|}{ Color } \\
\hline $\mathrm{H}_{2} \mathrm{SO}_{4} / \mathrm{EtOH} / \mathrm{H}_{2} \mathrm{O}(25: 50: 25)$ reagent & Yellowish brown & Brownish red & Grayish brown & Reddish brown \\
\hline
\end{tabular}

Silica Gel 60 PF-254 plates (Merck).

nd, Not detected; CX, cyclohexane; dd $^{\mathrm{a}}$ not detected because of overlapping signals with the other lignans.

hold $) \rightarrow 320^{\circ} \mathrm{C}\left(6^{\circ} \mathrm{C} \mathrm{min}^{-1}\right), 15$ min hold. The initial injector temperature $\left(160^{\circ} \mathrm{C}, 0 \mathrm{~min}\right.$ hold $)$ was raised to $260^{\circ} \mathrm{C}\left(8^{\circ} \mathrm{C} \mathrm{min}^{-1}, 15 \mathrm{~min}\right.$ hold $)$, while the detector temperature was kept at $320^{\circ} \mathrm{C}$. The chromatograms were processed using the TotalChrom software (Perkin Elmer Inc., Waltham, MA, USA). All the results, given in $\mathrm{mg} \mathrm{g}^{-1}$ or $\%\left(\mathrm{w} \mathrm{w}^{-1}\right)$, were calculated on a freeze-dried wood basis.

Identification of extractives using GC-MS: The HP 6890-5973 GCMSD instrument (Hewlett Packard, Palo Alto, CA, USA) was equipped with a 7683 autosampler and a HP-1 column (Agilent Technologies, Inc., Santa Clara, CA, USA; $25 \mathrm{~m} \times 0.20 \mathrm{~mm}$ i.d., film thickness $0.11 \mu \mathrm{m})$. The temperature of the MS transfer-line was $300^{\circ} \mathrm{C}$ and the MS ion source and quadrupole were kept at $230^{\circ} \mathrm{C}$ and $150^{\circ} \mathrm{C}$, respectively. The temperature of the injector was $280^{\circ} \mathrm{C}$. Helium was the carrier gas $\left(0.8 \mathrm{ml} \mathrm{min}^{-1}\right)$ and the injection was performed in a split mode (ratio 1:24). The column temperature program was as follows: $80^{\circ} \mathrm{C}$ ( 1 min hold $) \rightarrow 320^{\circ} \mathrm{C}\left(8^{\circ} \mathrm{C} \mathrm{min}^{-1}, 6\right.$ min hold $)$. The mass selective detector (MS-EI, $70 \mathrm{eV}$ ) worked in the range of $35-800 \mathrm{~m} / \mathrm{z}$. Commercial libraries (NIST98/WILEY275) and the spectral library of Åbo Akademi University served for substance identification.

Identification of extractives by HPLC: Extracts obtained by ASE were evaporated to dryness, dissolved in $\mathrm{MeOH}$ and filtered through a $0.22 \mu \mathrm{m}$ polyamide filter. Chemical screening of the extractives and purity evaluation of PS and PSMME were done by HPLC-photodiode array (HPLC-PDA) analysis (Accela 600, Thermo Scientific, Waltham, MA, USA) according to Vek et al. (2013) based on an octadecylsilyl (ODS) column (150 mm ×4.6 mm i.d., $2.6 \mu \mathrm{m}$ particle size, Accucore, Thermo Scientific), in which water and $\mathrm{MeOH}$ served as the mobile phase $\left(1000 \mu \mathrm{l} \mathrm{min}{ }^{-1}\right.$, total analysis time of $\left.30.2 \mathrm{~min}\right)$. The gradient system of elution: $5 \% \rightarrow 95 \%$ solvent B in $20 \mathrm{~min}$ with the following steps: $0-1 \mathrm{~min}$ : 5\% B constant; 1-21 $\mathrm{min}$ : 5\%-95\% phase B; 21-23 min: 95\% phase B constant; $23-23.10$ min: $95 \%-100 \%$ phase B; 23.10-25.10 min: $100 \%$ phase B constant; $25.10-25.20 \mathrm{~min}: 100 \%-5 \%$ phase B, and finally: $25.20-30.20$ min 5\% phase B constant before each new injection. The phenolic compounds were detected at $280 \mathrm{~nm}$, and trans-stilbene isomers were observed at $306 \mathrm{~nm}$ (Silva et al. 2014). The peaks were scanned by $\mathrm{UV}_{200 \rightarrow 400 \mathrm{~nm}}$, and the peak assignments were done based on retention time $\left(t_{R}\right)$ and ultraviolet (UV) spectral comparison with those of analytical standards.

${ }^{1} \mathrm{H}-\mathrm{NMR}$ spectroscopy: The $300 \mathrm{MHz}$ Unity Inova 300 Varian NMR spectrometer (Varian, Palo Alto, CA, USA) was used [dimethyl sulfoxide- $d_{6}\left(\right.$ DMSO- $\left.d_{6}\right)$ as the solvent, tetramethylsilane (TMS) as an internal standard, $25^{\circ} \mathrm{C}$ ]. Details: $90^{\circ}$ pulse angle, 5 -s delay between pulses, $5 \mathrm{~s}$ acquisition time, 32 repetitions, and peak integration using VNMRJ rev. 1.1D software (Varian, Palo Alto, CA, USA). The assignment of individual signals was performed according to the literature (Ngo and Brown 1998; Celimene et al. 1999).

\section{Results and discussion}

\section{Efficiency of extraction solvent systems}

As seen in Table 1, two hydrophilic and one lipophilic fraction were obtained. The hydrophilic fractions contained PS, PSMME and various lignans, of which the most abundant compounds were NTG and hydroxylmatairesinol (HMR), corresponding to pine knotwood and spruce knotwood, respectively (Figure 2).

The results of the GC-FID analysis of all the extracts are presented in Table 2, in which the yields of the individual components are summarized, namely PSMME, PS, fatty acids (FA) plus resin acids (RA), NTG and HMR 

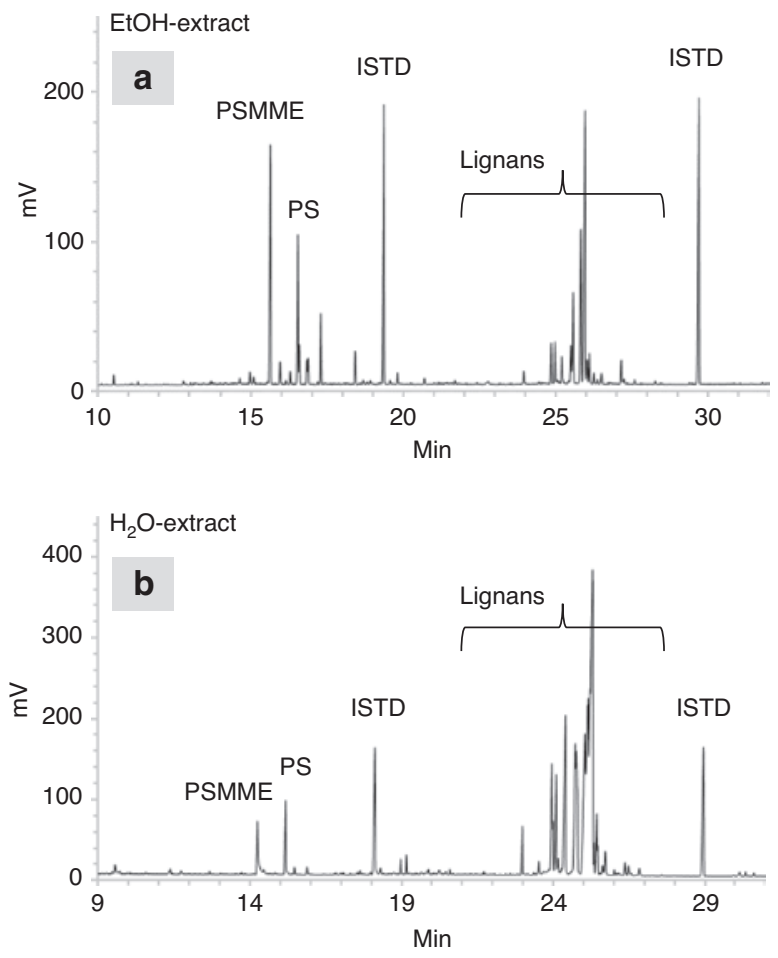

Figure 2: Higher content of PS and PSMME was obtained in EtOH-extract.

GC-FID chromatograms of (a) ethanol/water (95:5) extract and (b) $100 \%$ water extract of industrial wood residue sample.

obtained by individual extraction procedures. Quantitative GC-FID analysis of the hydrophilic EtOH extract revealed that the mixture of spruce and pine knotwood extracts contained about $7.9 \mathrm{mg} \mathrm{g}^{-1}$ of PSMME, $4.1 \mathrm{mg} \mathrm{g}^{-1}$ of PS, lignan NTG (3.1 $\left.\mathrm{mg} \mathrm{g}^{-1}\right)$ and the predominant lignan 7-hydroxymatairesinol (HMR - with two epimers), comprising $12.6 \mathrm{mg} \mathrm{g}^{-1}$ (based on freeze-dried wood). HMR was the main lignan in the spruce knotwood and NTG, in pine (Willför et al. 2003b).

The PS/PSMME ratio is dependent on the extraction solvent. For the sequential extraction with $\mathrm{CX}$ and $\mathrm{EtOH} /$ water as the solvents, $52 \%$ of PSMME of the total amount appeared in the CX extract (Table 2). The ratio of PS/ PSMME was lower in the case of EtOH/water (95:5) extraction. PS is better soluble in water due to its more polar nature while PSMME with one OMe group is a partially non-polar molecule and, consequently, less soluble in water, although it is very soluble in CX. This is the reason why the PS/PSMME ratio was higher with water as the extraction solvent (Figure 2). The total yields were high, but the selectivity for phenolic compounds was low.

Sequential extraction with CX and EtOH/water (95:5) yielded higher amounts of the compounds PS, PSMME and NTG, than that in the case of non-sequential extraction with water. CX was an effective and selective solvent for both FA and RA and PSMME. On the other hand, the amounts of PS (2.6 $\left.\mathrm{mg} \mathrm{g}^{-1}\right)$ and PSMME (3.3 $\left.\mathrm{mg} \mathrm{g}^{-1}\right)$ in the water extract were relatively low (Table 2, Figure 2) and the quantity of PSMME was lower than that in the EtOH/water extract. As previously mentioned, this is due to the semipolar character of PSMME. A relatively high percentage of polysaccharides and traces of various RAs (e.g. pimaric and abietic acids) are characteristic of the water extract.

After GC analysis, the extracts of the industrial knotwood were further analyzed by HPLC. The results showed linearity in the selected concentration range $\left(1.56 \mathrm{mg} \mathrm{l}^{-1}\right.$ to $\left.100 \mathrm{mg} \mathrm{l}^{-1}\right)$ for all the reference compounds $\left(R^{2} \geq 0.99\right)$. The separation of the reference mixture gave a chromatogram with the following elution order: NTG [11.7 $\mathrm{min}$ $\mathrm{t}_{\mathrm{R}}$ ], PB (13.9 $\min \mathrm{t}_{\mathrm{R}}$ ), PS (15.3 $\min \mathrm{t}_{\mathrm{R}}$ ), PiSb (14.5 $\min \mathrm{t}_{\mathrm{R}}$ ), PC $\left(16.5 \min _{\mathrm{R}}\right.$ ), PtSb (17.6 min $\mathrm{t}_{\mathrm{R}}$ ) and PSMME (17.9 $\min \mathrm{t}_{\mathrm{R}}$ ). The total time of analysis was $30.2 \mathrm{~min}$ (Figure 3). The first compound eluted from the previously mentioned ODS column was NTG, which is also the most polar of the reference compounds, and PSMME eluted last due to its partially non-polar character. The most abundant peaks were assigned to NTG, PS and PSMME (Figure 3). The distinction between NTG and HMR was not possible for the HPLC of the EtOH/water (95:5) extract.

\section{Mobile phases of the TC}

For the isolation of individual compounds by flash chromatography, it was necessary to find the most suitable mobile phase. Four different solvent systems were tested in different ratios (v/v): CX/EtOAc, CX/acetone, $\mathrm{CH}_{2} \mathrm{Cl}_{2} / \mathrm{EtOH}$ and EtOAc/PET. In Table 3, the $\mathrm{R}_{\mathrm{F}}$ values for the stilbenes, PSMME and PS, and the lignans NTG and HMR with a series of solvent systems are listed. Satisfactory separation of the components with discernible distances between the spots of PS, PSMME, NTG and HMR was obtained with the solvent systems (a) CX/EtOAc, (b) $\mathrm{CH}_{2} \mathrm{Cl}_{2} / \mathrm{EtOH}$ and (c) PET/EtOAc. The solvent system CX/ EtOAc was selected for a large-scale purification of the extracts. The reference solvent system $\mathrm{CH}_{2} \mathrm{Cl}_{2} / \mathrm{EtOH}$ was eliminated because of its chlorinated component, and PET/EtOAc was not considered either, because petrol ether is not a well-defined (pure) solvent.

Three different spots were observed on the TLC plates. The first, with the highest $R_{\mathrm{F}}$, was PSMME, the second was PS, and the last was NTG (Table 3). The spot at the starting position of the TLC plates represents the two isomers of HMR, which were eluted during flash column chromatography with 100\% EtOAc (Table 3, Figure 5b). 


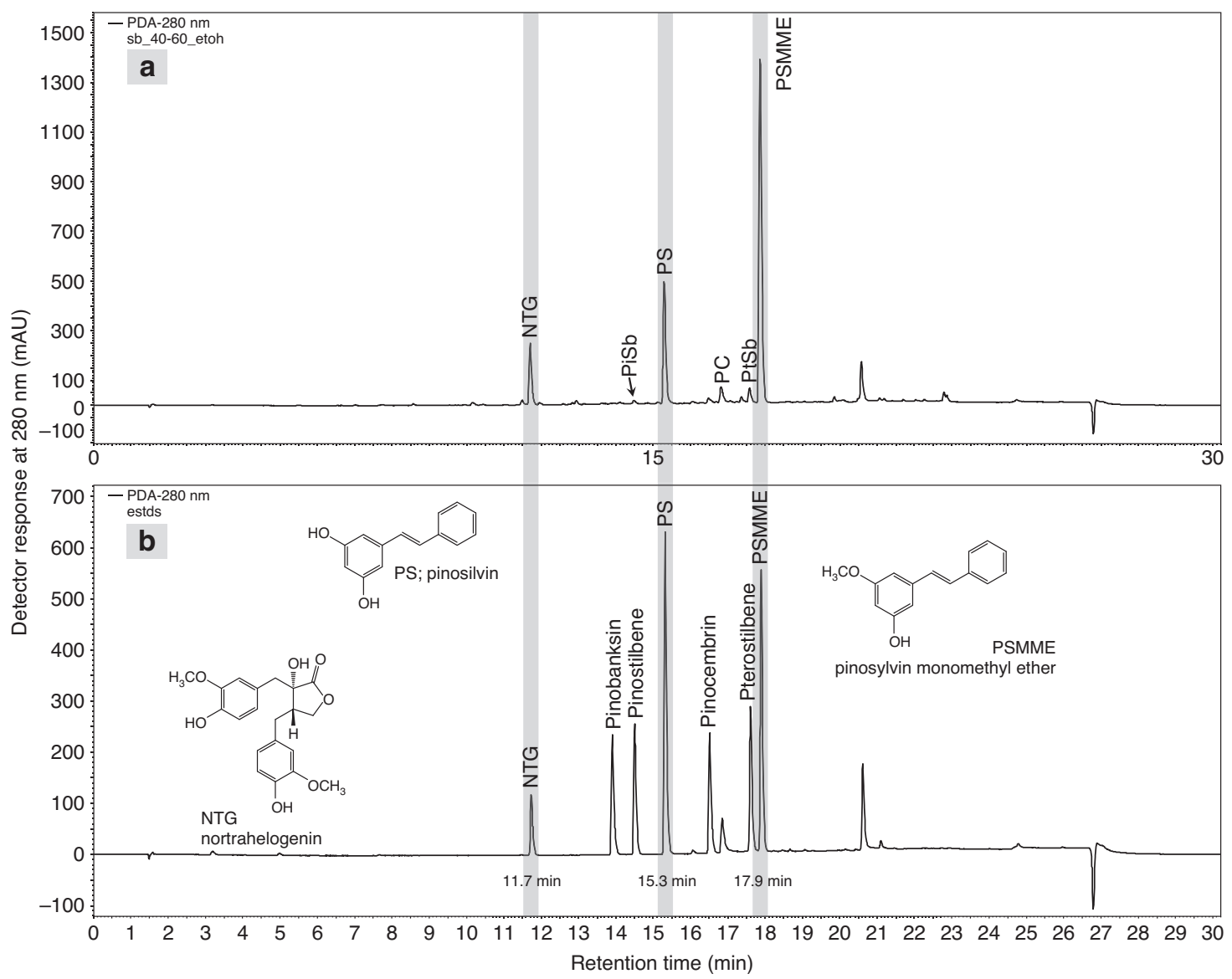

Figure 3: Identification of compounds in EtOH-extract was done by comparison of $\mathrm{t}_{\mathrm{R}}$ of external standards (estds). HPLC chromatogram monitored at $280 \mathrm{~nm}$ of (a) ethanol extract of the industrial wood residue sample (sb_40-60_etoh) and (b) mixture of reference compounds (estds).

\section{Isolation of pure pinosylvins (PS)}

Water and EtOH extracts were treated with different purification methods because the quantity and PS/PSMME ratio in the water extract were low (Table 2). For the purification of the water extract, isolation of PS and PSMME was attempted with L-L extraction using EtOAc, while $\mathrm{NaCl}$ was added to the aqueous extract to increase its ionic strength. As a result, the major part of the PS and PSMME could be extracted by EtOAc. Polysaccharides have low solubility in the semi-polar EtOAc in contrast to the high solubility of PS and lignans, so PS and polysaccharides could be well separated.

Flash column chromatography was tested for the separation of PS and its derivatives from lignans. Various $\mathrm{CX} / \mathrm{EtOAc}$ ratios with different volumes were tested in the gradient separation mode. The mixture of $\mathrm{CX}$ and EtOAc turned out to be promising: $500 \mathrm{ml}$ of $100 \% \mathrm{CX}$ followed by a mixture of $1500 \mathrm{ml}$ of CX/EtOAc (80/20), $1000 \mathrm{ml}$ of CX/EtOAc (60/40) and $500 \mathrm{ml}$ of $100 \%$ of EtOAc; the column was finally flushed with $500 \mathrm{ml}$ of $100 \%$ acetone.
Two consecutive flash column chromatography runs were performed to obtain pure PS. The first batch was obtained via the raw hydrophilic EtOH extraction, while for the second batch, only the fractions 21-26 of the first flash chromatography were combined and re-chromatographed. Pure PS was obtained after the second run. For individual compound identification, the samples were separated on a long capillary column by GC-MS, while MS means a quadrupole mass selective detector (MSD). In Figure 4, the GC-MSD and GC-electron ionization (EI)-MS spectra of isolated pure PS from EtOH/water (95/5) extract are presented. The other results are presented in Figure 5. In Figure 5a, the main peak on the GC chromatogram represents the lignan NTG, which appeared as the last spot on the TLC plate. The GC of the last fraction obtained by flash chromatography with $100 \%$ EtOAc is seen in Figure 5b. Two epimers of the lignan HMR were detectable by GC.

The isolated PSs were further checked by LC at $306 \mathrm{~nm}$, as this wavelength is suitable for the monitoring of trans-stilbene isomers (Silva et al. 2014). The HPLC 
a

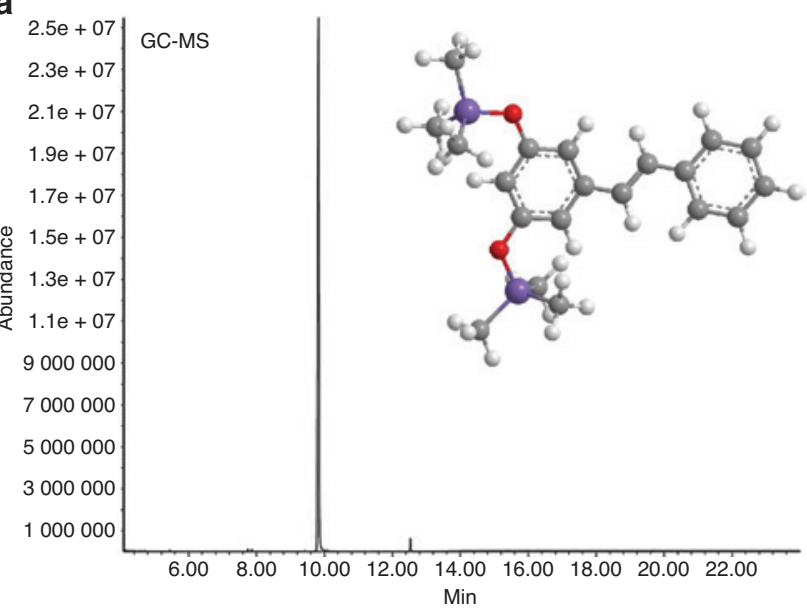

b

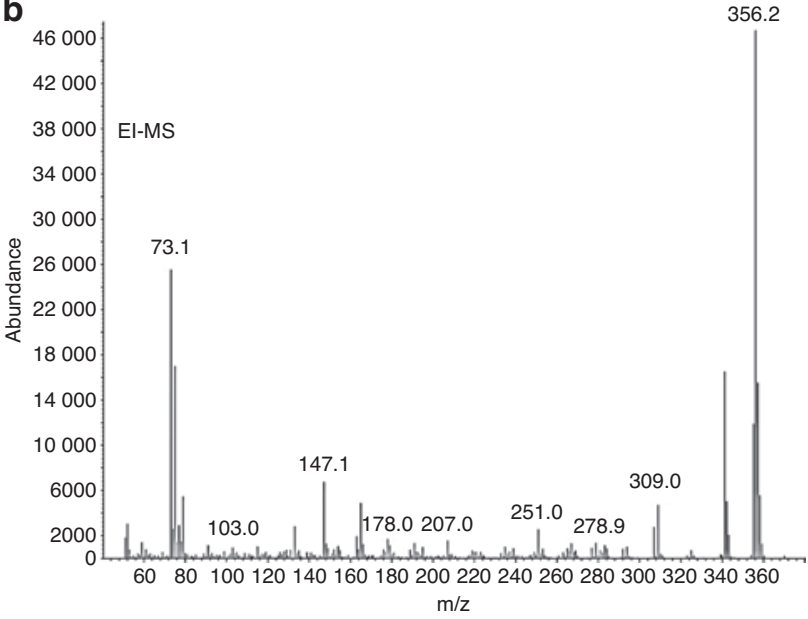

Figure 4: The GC-MSD and GC-electron ionization (EI)-MS spectra.

(a) GC-MS and (b) El-MS spectrum of isolated derivatized pinosylvin from ethanol/water (95:5) extract.

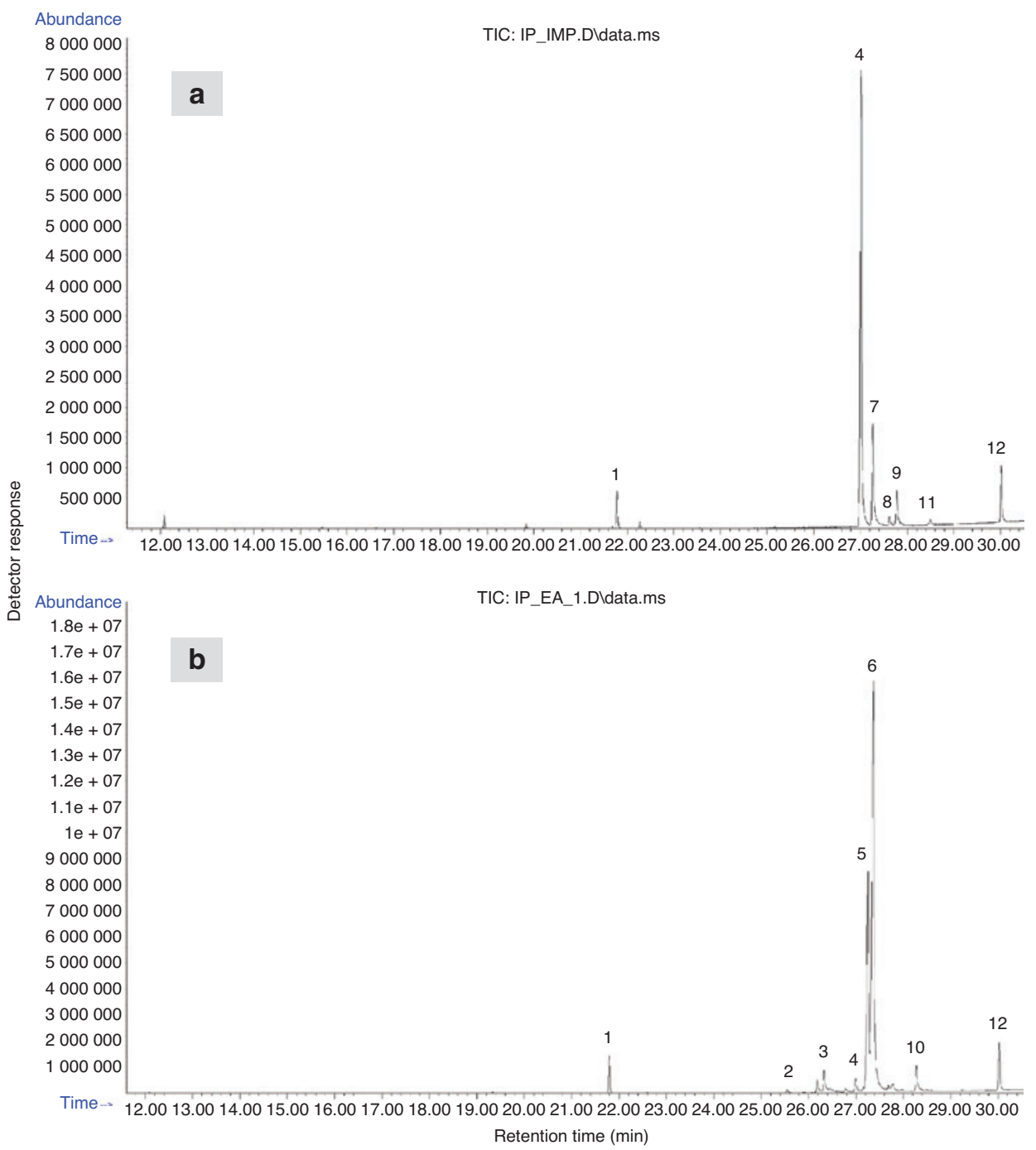

Figure 5: GC-MS confirmed the separation of NTG and HMR by flash chromatography.

Total ion current GC-MS of (a) the last spot on TLC plates purified and isolated by as flash chromatography and (b) the $100 \%$ ethyl acetate fraction obtained by flash chromatography. Peak assignment: 1: C21:0 internal standard (ISTD), 2: 7R-todolactol, 3: 7S-todolactol, 4: NTG, 5: HMR 1, 6: HMR 2, 7: matairesinol, 8: NTG (8'-OH not silylated), 9: conidendrin, 10: iso-HMR, 11: pinoresinol, 12: betulinol (ISTD). 


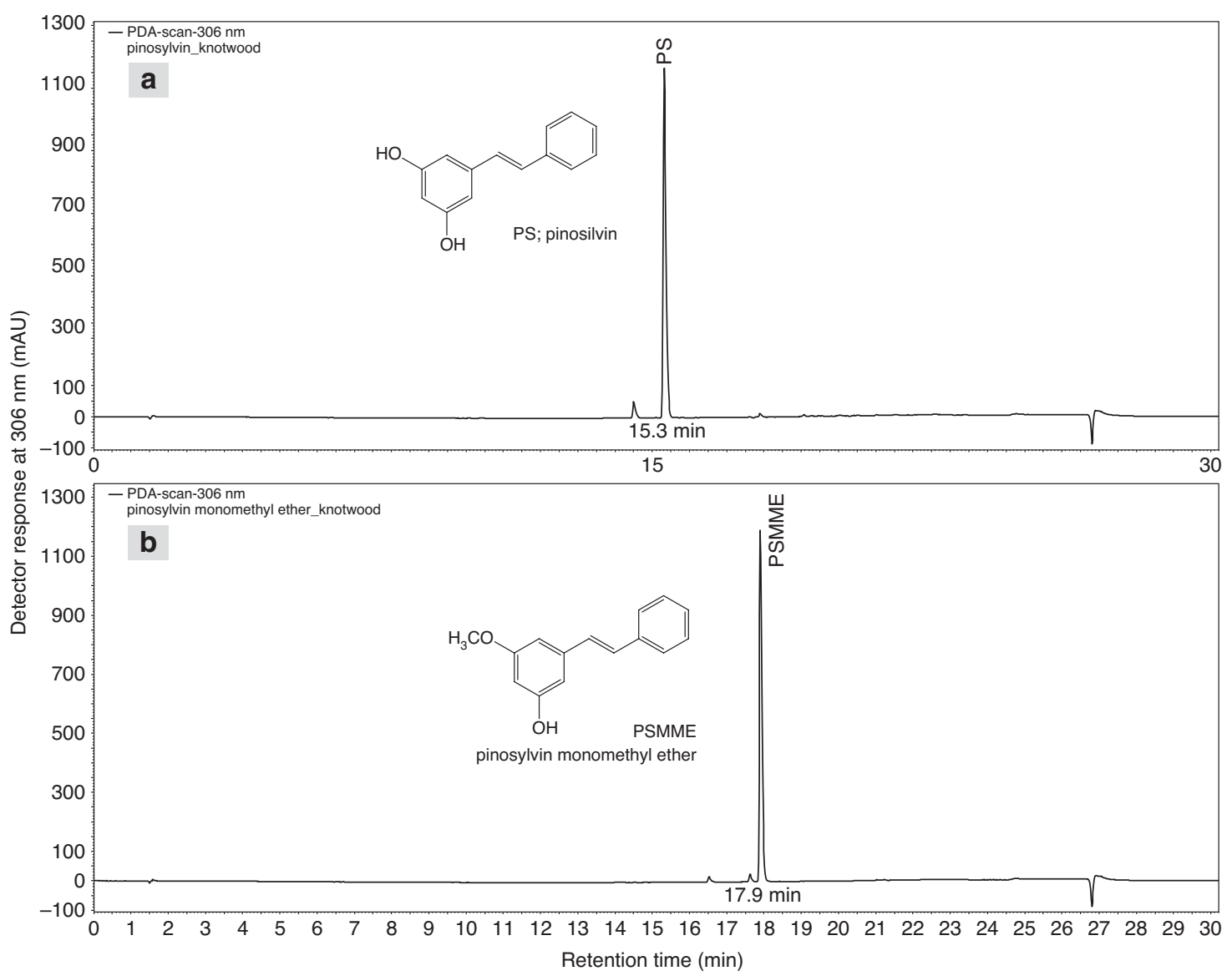

Figure 6: The purity of isolated PS and PSMME was $96 \%$.

HPLC chromatograms monitored at $306 \mathrm{~nm}$ of (a) PS and (b) PSMME isolated from the industrial knotwood sample.

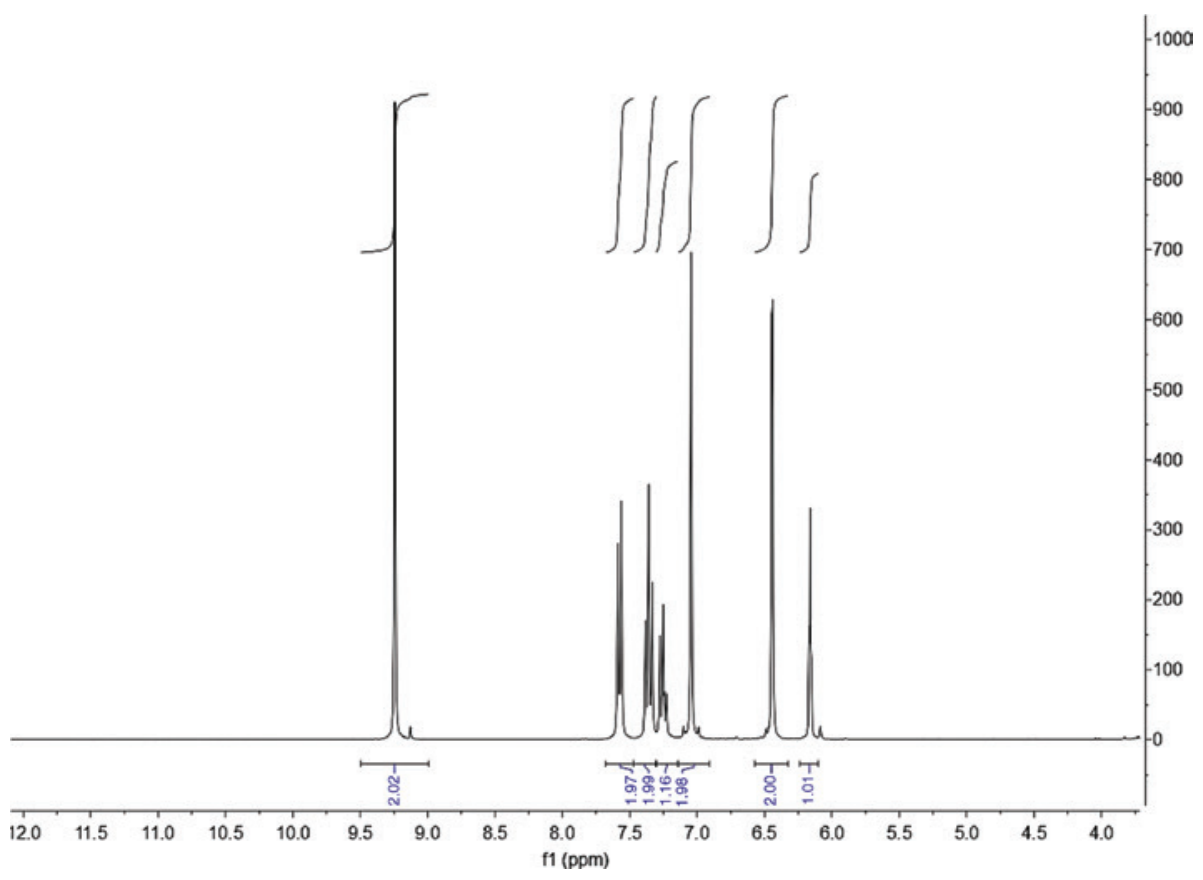

Figure 7: ${ }^{1} \mathrm{H}-\mathrm{NMR}$ spectrum of PS. 
separation of pure isolated PS and PSMME is presented in Figure 6, and a 96\% purity of the compounds was attested.

The ${ }^{1} \mathrm{H}$-NMR PS spectrum in DMSO- $\mathrm{d}_{6}$ is presented in Figure 7. The signal at $9.25 \mathrm{ppm}(2 \mathrm{H}, \mathrm{s},-\mathrm{OH})$ corresponds to the $-\mathrm{OH}$ protons in PS, which was not observed in the ${ }^{1} \mathrm{H}-$ NMR spectrum of PS in $\mathrm{CDCl}_{3}$. The doublet at $7.57 \mathrm{ppm}(2 \mathrm{H}$, $\mathrm{d}, \mathrm{J}=7.2 \mathrm{~Hz}-\mathrm{H}_{\mathrm{Ar}}$ ) represents the ortho protons of unsubstituted aromatic rings, and the signal at $7.36 \mathrm{ppm}(2 \mathrm{H}, \mathrm{dd}$, $\mathrm{J}=7.5 \mathrm{~Hz}, \mathrm{~J}=15 \mathrm{~Hz},-\mathrm{H}_{\mathrm{Ar}}$ ) corresponds to the meta aromatic protons of the unsubstituted aromatic ring. The doublet at $7.28 \mathrm{ppm}\left(1 \mathrm{H}, \mathrm{dd}, \mathrm{J}=7.5 \mathrm{~Hz}, \mathrm{~J}=15 \mathrm{~Hz},-\mathrm{H}_{\mathrm{Ar}}\right)$ represents one aromatic proton at the para position of the unsubstituted aromatic ring (Figure 7). The proton signal of a double bond appears at $7.05 \mathrm{ppm}\left(2 \mathrm{H}, \mathrm{s},-\mathrm{H}_{\mathrm{Ar}}\right)$. The doublet at $6.44 \mathrm{ppm}\left(2 \mathrm{H}, \mathrm{d}, \mathrm{J}=2.1 \mathrm{~Hz},-\mathrm{H}_{\mathrm{Ar}}\right)$ corresponds to the ortho protons of the substituted aromatic ring. The proton in the para position of the substituted aromatic ring appears at 6.16 as a doublet $\left(2 \mathrm{H}, \mathrm{dd}, \mathrm{J}=2.1 \mathrm{~Hz}, \mathrm{~J}=4.2 \mathrm{~Hz}-\mathrm{H}_{\mathrm{Ar}}\right)$.

\section{Conclusions}

It was demonstrated that an industrial residue consisting of a mixture of Scots pine and Norway spruce wood can be efficiently and sequentially extracted by pressurized solvent extraction with non-polar (CX) and polar (EtOH/water, 95/5) solvents. The most abundant compounds were the lignans, HMR and NTG, together with the stilbenes, PS and PSMME, indicating the presence of spruce and pine knotwood in the sample. CX yielded the highest amount of PSMME and EtOH/water 95:5 yielded the highest amount of PS. Hot water extraction gave lower amounts of PS and PSMME.

The novelty of this contribution is the presentation of a convenient and environmentally friendly method for the extraction, isolation and purification of PSs, which can be realized on an industrial scale without chlorinated solvents. TLC was proven to be a useful method for the fast screening of extracts and for preparative separation of stilbenes for further studies by flash chromatography, GC and HPLC. The presented method has a potential for scaling up in modern lignocellulosic biorefineries.

Acknowledgments: This work was conducted within the frame of the WoodWisdom ERA NET transnational project PINOBIO. The Slovenian part of the project was partially supported by the Ministry of Education, Science and Sport of the Republic of Slovenia within the Programme Group P4-0015. We thank Assistant Professor Annika Smeds for the GC-MS analyses. This work was also part of activities at the Johan Gadolin Process Chemistry Centre, a Centre of Excellence of the Åbo Akademi University.

Author contributions: All the authors have accepted responsibility for the entire content of this submitted manuscript and approved submission.

Research funding: None declared.

Employment or leadership: None declared.

Honorarium: None declared.

\section{References}

Allen, L.H. (1980) Mechanisms and control of pitch deposition in newsprint mills. Tappi 63:81-87.

Celimene, C., Micales, J., Ferge, L., Young, R. (1999) Efficacy of pinosylvins against white rot and brown rot fungi. Holzforschung 53:491-497.

Chan, M.M.-Y. (2002) Antimicrobial effect of resveratrol on dermatophytes and bacterial pathogens of the skin. Biochem. Pharmacol. 63:99-104.

Conde, E., Fang, W., Hemming, J., Willför, S., Domínguez, H., Parajó, J. (2014) Recovery of bioactive compounds from Pinus pinaster wood by consecutive extraction stages. Wood Sci. Technol. 48:311-323.

Eckerman, C., Holmbom, B. (2001) Method for recovery of compression wood and/or normal wood from oversize chips. In PCT/ Fl101/00691. WO 02/09893 A1 (Finn.).

Fang, W., Hemming, J., Reunanen, M., Eklund, P., Pineiro Enma, C., Poljanšek, I., Oven, P., Willför, S. (2013) Evaluation of selective extraction methods for recovery of polyphenols from pine. Holzforschung 67:843-851.

Farrell, R.L., Blanchette, R.A., Brush, T.S., Hadar, Y., Iverson, S., Krisa, K., Wendler, P.A., Zimmerman, W. (1993) Cartapip (TM) - a biopulping product for control of pitch and resin acid problems in pulp-mills. J. Biotechnol. 30:115-122.

Gutierrez, A., del Rio, J.C., Martinez, M.J., Martinez, A.T. (2001) The biotechnological control of pitch in paper pulp manufacturing. Trends Biotechnol. 19:340-348.

Lindberg, L.E., Willför, S.M., Holmbom, B.R. (2004) Antibacterial effects of knotwood extractives on paper mill bacteria. J. Ind. Microbiol. Biotechnol. 31:137-147.

Ngo, K.S., Brown, G.D. (1998) Stilbenes, monoterpenes, diarylheptanoids, labdanes and chalcones from Alpinia katsumadai. Phytochemistry 47:1117-1123.

Nilsson, M., Wikman, S., Eklund, L. (2002) Induction of discolored wood in Scots pine (Pinus sylvestris). Tree Physiol. 22:331-338.

Pietarinen, S., Willför, S., Ahotupa, M., Hemming, J., Holmbom, B. (2006) Knotwood and bark extracts: strong antioxidants from waste materials. J. Wood Sci. 52:436-444.

Plumed-Ferrer, C., Väkeväinen, K., Komulainen, H., Rautiainen, M., Smeds, A., Raitanen, J.-E., Eklund, P., Willför, S., Alakomi, H.-L., Saarela, M., von Wright, A. (2013) The antimicrobial effects of wood-associated polyphenols on food pathogens and spoilage organisms. Int. J. Food Microbiol. 164:99-107.

Simard, F., Legault, J., Lavoie, S., Mshvildadze, V., Pichette, A. (2008) Isolation and identification of cytotoxic 
compounds from the wood of Pinus resinosa. Phytotherapy Res. 22:919-922.

Silva, F., Figueiras, A., Gallardo, E., Nerin, C., Domingues, F.C. (2014) Strategies to improve the solubility and stability of stilbene antioxidants: a comparative study between cyclodextrins and bile acids. Food Chem. 145:115-125.

Välimaa, A.-L., Honkalampi-Hämäläinen, U., Pietarinen, S., Willför, S., Holmbom, B., von Wright, A. (2007) Antimicrobial and cytotoxic knotwood extracts and related pure compounds and their effects on food-associated microorganisms. Int. J. Food Microbiol. 115:235-243.

Vek, V., Oven, P., Poljansek, I. (2013) Quantitative HPLC analysis of catechin in wound-associated wood and knots of beech. Drvna Ind. 64:231-238.
Willför, S., Hemming, J., Reunanen, M., Holmbom, B. (2003a) Phenolic and lipophilic extractives in Scots pine knots and stemwood. Holzforschung 57:359-372.

Willför, S., Hemming, J., Reunanen, M., Eckerman, C., Holmbom, B. (2003b) Lignans and lipophilic extractives in Norway spruce knots and stemwood. Holzforschung 57:27-36.

Willför, S., Ahotupa, M.O., Hemming, J.E., Reunanen, M.H.T., Eklund, P.C., Sjoholm, R.E., Eckerman, C.S.E., Pohjamo, S.P., Holmbom, B.R. (2003c) Antioxidant activity of knotwood extractives and phenolic compounds of selected tree species. J. Agricult. Food Chem. 51:7600-7606.

Willför, S., Hafizo glu, H., Tümen, I., Yazici, H., Arfan, M., Ali, M., Holmbom, B. (2007) Extractives of Turkish and Pakistani tree species. Eur. J. Wood and Wood Prod. 65:215-221. 